EUROPA REGIONUM TOM XXIII ROK 2015

DOI: $10.18276 /$ er.2015.23-13

DARINA ELIAŠOVÁ

Ekonomická Univerzita Obchodná fakulta Bratislava

\title{
Pozycja uzdrowiska Cerwony Klastor-Smerdzonka w słowacko-polskim rejonie przygranicznym
}

\section{Wprowadzenie}

W dniu 26 sierpnia 1994 roku przedstawiciele polskich i słowackich samorządów Podhala, Liptowa, Orawy i Spisza, na założycielskim kongresie w Nowym Targu podpisali Umowę między samorządami Polski i Słowacji o powołaniu transgranicznego zespołu Euroregion Tatry - z siedzibą w Nowym Targu po stronie polskiej i w Kezmarku po stronie słowackiej. Euroregion Tatry stosuje zasady uniwersalnej współpracy między obywatelami, instytucjami i przedstawicielami jednostek samorządów polsko - słowackich.

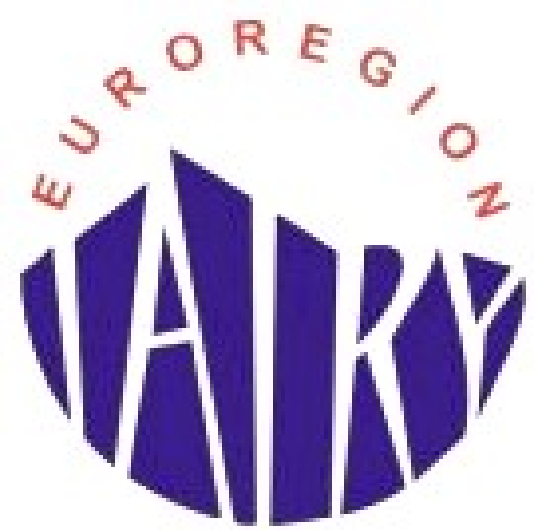

Rysunek 1. Logo Euroregionu Tatry

Źródło: Euroregion Tatry. 
Obszar Euroregionu Tatry obejmuje także Pieniny, które spełniają wymóg zbliżania ludzi poprzez turystykę. Według regionalizacji ruchu turystycznego Republiki Słowackiej, Pieniny są częścią rejonu tatrzańskiego oznaczone subregionem Pieniny. W Pieninach utworzono pierwszy międzynarodowy park w Europie. Konwencja w sprawie ochrony światowego dziedzictwa kulturalnego i naturalnego potwierdza wyjątkowość jego terytorium. Według Światowej Unii Ochrony Przyrody (IUCN) w parkach narodowych są dozwolone tylko dwa rodzaje działalności: ochrona przyrody i rekreacji. Połączenie dwóch elementów znajduje odzwierciedlenie $\mathrm{w}$ tak zwanej turystyce ekologicznej. W ramach aktywnego wypoczynku turystyka jest dopuszczalna pod warunkiem, że nie szkodzi naturze i nie zagraża parkowi narodowemu. Według Europejskiej Federacji Parków Narodowych i Naturalnych chodzi o wszystkie formy rozwoju turystyki, zarządzania i działalności, które utrzymują integralność środowiska społecznego i gospodarczego oraz zapewniają długotrwałe użytkowanie zasobów naturalnych i kulturowych. Obszar Pienińskiego Parku Narodowego po słowackiej stronie to 3749 hektarów, wielkość strefy buforowej to 2244 hektarów, znajduje się w Spiskiej Starej Wsi.

Tabela 1

Charakterystyka Pienińskiego Parku Narodowego w Polsce

\begin{tabular}{|l|r|l|r|l|r|r|c|}
\hline & \multicolumn{1}{|c|}{$\mathrm{km}^{2}$} & & $\mathrm{~km}^{2}$ & & $\mathrm{~km}^{2}$ & & $\mathrm{~km}^{2}$ \\
\hline Powierzchnia & 23,46 & Pow. ochrony & & Pow. ochrony & & & \\
- leśna & 16,65 & - ścisłej & 7,50 & - ścisłej & 7,50 & Pow. & \\
- uprawna & 4,71 & - częściowej & 5,05 & - częściowej & 5,05 & otuliny & 26,82 \\
- wodna & 0,32 & - krajobrazu & 10,91 & - krajobrazu & 10,91 & & \\
\hline
\end{tabular}

Źródło: opracowanie własne na podst. http:// wiki/Pieniński_Park_Narodowy.

W Pieninach znajdują się dwa uzdrowiska - Cerwony Klastor na Słowacji i Szczawnica po stronie polskiej. Stwarzają one warunki dla rozwoju partnerstwa wschodzącej ekoturystyki. Wejście Republiki Słowackiej i Rzeczypospolitej Polskiej do Unii Europejskiej otworzyło pienińską granicę w szczególności dla celów turystyki, rekreacji i wypoczynku w ekologicznie atrakcyjnym środowisku.

Pieniny dla celów związanych z rekreacją są wykorzystywane od pierwszej połowy XVIII wieku wraz z rozwojem uzdrowiska Szczawnica, które było celem turystów korzystających ze szlaków w Pieninach i osób korzystających 
ze spływu po rzece Dunajec. Spływ odbywał się na tradycyjnych drewnianych tratwach ze Sromowiec Niżnych lub Niżnych Szwabii. Piesze wycieczki i spływ po rzece Dunajec są oprócz innych zajęć rekreacyjnych, atrakcją turystyczną. Początki rozwoju turystyki w Pieninach przedstawił Józef Szalay ${ }^{1}$ w serii rysunków artystycznych, które zostały przekazane do muzeum Pienińskiego w Szczawnicy. Pobyt rekreacyjny na tym terenie wynikał nie tylko z istnienia wód mineralnych, dobrego klimatu, ale w większości z naturalnego środowiska Pienin. Znajdują się tu lecznice, miejsca rekreacyjne a także obiekty socjalne. Tworzenie uzdrowiska Smerdžonka na początku XIX wieku w oparciu o zimne źródła Glauber (wody siarki) służyło do stymulowania wzajemnej wiedzy i współpracy dwóch uzdrowisk.

Rozwój wymienionych uzdrowisk był jednak inny. Choć funkcja uzdrowiska Smerdžonka w latach 60. XX wieku zniknęła, to Szczawnica systematycznie się rozbudowywała, pomimo faktu, że zasięg i pojemność wody mineralnej nie w pełni zaspokajał potrzeby stosunkowo dużej liczby przedsiębiorców i turystów. Obecnie Szczawnica to znane i ładnie zbudowane uzdrowisko, które staje się atrakcją ruchu turystycznego także po słowackiej części Pienin.

Celem artykułu jest scharakteryzowanie ekoturystyki w Pieninach, koncentrując się na turystyce uzdrowiskowej w ośrodkach zdrowia Czerwony Klasztor-Smerdžonka w kontekście badania zasobów naturalnych, leczniczych i ich zastosowania do leczenia oraz wypoczynku. Znaczne informacje uzyskano badaniem w archiwach państwowych Republiki Słowackiej i za granica. Były to aktualne informacje podjętych badań w uzdrowiskach, materiały pierwotne i wtórne, badania zasobów naukowych i technicznych, a także wywiady z osobami, które mogłyby być lokalnymi przewodnikami, gdyż dużo pamiętały z tamtych lat. Metodę czasowych i przestrzennych porównań wykorzystano w badaniu rozwoju uzdrowiska od najstarszego do dnia dzisiejszego.

${ }^{1}$ Józef Szalay zainicjował całkowitą przebudowę Szczawnicy. Przede wszystkim przekonał górali do przebudowy swoich domostw w taki sposób, aby mogli przyjmować turystów. Wyznaczył i stworzył Park Zdrojowy, w którym kuracjusze mogli odpoczywać i prowadzić spotkania towarzyskie. W jego zasługi należy wpisać także powstanie licznych pensjonatów w stylu szwajcarskim, http://www.szczawnica.nrs.pl/. 


\section{Krótki zarys historii Smerdžonki}

Smerdžonka przez wieki była częścią červenokláštorského państwa, które na przemian było w rękach właścicieli świeckich i kościelnych. Najstarsze zapisy o Smerdžonce pochodzą z kamedulskich zapisów z początku XVIII wieku, gdzie jest określana jako balneum, w związku z wynajmem „knajpy przy uzdrowisku". Zapis pokazuje, że wody lecznicze Smerdžonka były używane, niewiadomo w jakim celu. Po zniesieniu zakonu kamedułów w $1782 \mathrm{r}$. Smerdžonka wraz z innymi religijnym majątkami należała do funduszu nabożeńskiego (Fundus religionis). Lekarz Dr Johann Jacob von Engel w rękopisie pracy o Smerdžonce z 1823 roku mówi, że w 1805 roku Smerdžonka należała do młynarza z pobliskiego młyna, który oferował ciepłą kąpiel w drewnianej wannie w jego ,szopie”.

W 1820 r. Smerdžonka staje się własnością biskupstwa greckokatolickiego w Preszowie, które zbudowało pierwszy budynek uzdrowiska w 1824 r. Ten rok można uznać za początek budowy i tworzenia stosunkowo niewielkiego środowiska. Nawet greckokatolicie biskupstwo dało restaurację z uzdrowiskiem do wynajęcia; na przykład w roku 1844 za 1200 sztuk złota (zbudowane łaźnie z kamienia i cegły). Zawierały one duży salon i z obu stron cztery przestronne pokoje dzienne, oraz salon połączony z loggią. Zbudowanie łaźni Smerdžonka wiąże się z powstaniem miejsca rekreacji uzdrowiskowej w Pieninach. ${ }^{2}$

$\mathrm{Na}$ podstawie rozporządzenia Ministra Węgierskiego Zgromadzenia Ogólnego Spiszu z dnia 21 grudnia 1887 r. - oficjalnie Smerdžonka zostaje uzdrowiskiem. W roku 1905 r. grekokatolicke biskupstwo sprzedało Smerdžonkę konsorcjum biskupstwa żydowskiego, które następnie, w 1907 r., sprzedał państwu węgierskiemu. W łaźniach publicznych Smerdzonka zostały zbudowane pokoje Spa z wanną i basenem. Operacja trwała do początku I wojny światowej. Podczas wojny uzdrowisko służyło jako szpital wojskowy i schronisko dla żołnierzy czesko-słowackich. Budynki uzdrowiska zostały częściowo zniszczone, niektóre najbardziej uszkodzone. Po utworzeniu Czechosłowacji łaźnie były zamknięte, a nawet w 1920 r. nie miały urządzenia wewnętrznego.

${ }^{2}$ Przewodnik turystyczny po Zamagurzu Spiskim, Projekt współfinansowany przez Unię Europejską z Europejskiego Funduszu Rozwoju Regionalnego oraz z budżetu państwa za pośrednictwem Euroregionu „Tatry” w ramach Programu Współpracy Transgranicznej Rzeczpospolita Polska-Republika Słowacka 2007-2013. Towarzystwo Słowaków w Polsce, Zarząd Oddziału na Spiszu, Kraków 2014. 
Następny remont miał miejsce w 1928 r. W celu leczenia chorób reumatycznych i skórnych, korzystanie z dwóch baterii alkalicznych - sulfatickich źródeł, dostarczające wodę leczniczą dla osiemnastu wanien w budynku uzdrowiska. Był tutaj hotel i dwie wille z 26 pokojami. Otaczający las był przeznaczony do spacerów. Do korzystania był basen z podgrzewaną wodą siarki i sześć nowych kabin. Uzdrowisko cieszyło się dużą popularnością, przede wszystkim klientów z Czech. Uzdrowisko i hotel były w dobrze utrzymanym parku gdzie hodowano wysokie róże, drzewa iglaste i liściaste. Przy wejściu do parku stała Vila Tiso, nazwana według Ministra Zdrowia Czechosłowacji, a później prezydent Republiki Słowackiej Józefa Tiso, dzięki któremu nastąpiło ożywienie uzdrowiska. Uzdrowisko Smerdžonka prowadzili Simon i Esti Teichnerovci aż do ich deportacji do obozów koncentracyjnych, z których już nie wrócili.

Podczas drugiej wojny światowej kąpiele Smerdžonka zostały przeznaczone dla armii wojennych po obu stronach frontu. Oczywiście, że w dużej mierze zostały zniszczone, więc działalność w okresie powojennym została naruszona. W roku 1946 w tym miejscu powstało środowisko rekreacyjne Pionier, które w dużej mierze koncentrowało się na rekreacji dziecięcej. W budynku, który już dziś nie istnieje, pozostało sześć wanien, basen, który później był przekształcony w saunę. W kompleksie uzdrowiska znajdowała się restauracja, park uzdrowiskowy, stragany, altanek na koncerty okolicznościowe, poczta, a naprzeciwko uzdrowiska znajdował się hotel turystyczny Dunajec. Hotele tatrzańskie z siedzibą firmy w Starym Smokowcu, pod nazwą Czerwony Klasztor - uzdrowiska działały do 1969 r. Zamknięcie uzdrowiska jest związane z konwersją na środowisko rekreacyjne ZV ROH Chemko Strazske. Dużo inwestowano w to przedsiębiorstwo. Na miejscu ośrodku zdrowia (dawnej willi Tiso) zostały zbudowane trzy domki rekreacyjne i kolejne trzydzieści domków w innej części ośrodka z linkami do wyciągu narciarskiego. Przeprowadzono również remont linii energetycznych i wprowadzono centralne ogrzewanie. W 2002 r. została przeprowadzona prywatyzacja.

\section{Obecność uzdrowiska Czerwony Klasztor - Smerdžonka}

W wyniku prywatyzacji utworzono firmę PIENINY RESORT s.r.o. Firma na zamówienie dała wykonać eksplorację hydrogeologiczną wód mineralnych w Czerwonym Klasztorze-Smerdžonka. Badanie zostało przeprowadzone 
przez TERRATEST, s.r.o. Żylina. Zgodnie z ustawą nr 538/2005Sb o naturalnych wodach leczniczych, naturalnych uzdrowiskach leczniczych, obiektów uzdrowiska i naturalnych wód mineralnych. Badanie źródła potwierdziło, iż spełnia kryteria naturalnej wody leczniczej. Komisja w 2012 r., oświadczyła, iż uzdrowisko Czerwonego Klasztoru spełnia wymogi naturalnego źródła leczniczego i pozwoliła na funkcjonowanie jako naturalnego uzdrowiska. Dla ochrony naturalnych zasobów leczniczych zostały zidentyfikowane strefy pierwszej i drugiej instancji.

Uzdrowisko Czerwony Klasztor - Smerdžonka koncentruje się na pacjentach powyżej 18 roku życia. Choroby skórne wskazanie - przewlekłe lub nawracające wypryski, miejscowe i uogólnione formy, atopowe zapalenie skóry, objawy przewlekłe, łuszczyca, przyłuszczyca, przewlekłe dermatozy w tym rybiej łuski, oparzenia chemiczne i niektóre formy trądziku. Projekt uzdrowiska jest zgodny z naturą źródła balneologii, w związku z tym operator jest uprawniony do korzystania z zasobów do celów medycznych i balneoterapii. Uzdrowisko jest odpowiednie do leczenia układu mięśniowo-szkieletowego, chorób neurologicznych i zaburzeń układu pokarmowego. Siarkowodór jest dobrze wchłaniany przez skórę i błony śluzowe. Ma działanie przeciwbólowe, przeciwzapalne i antyseptyczne, a w tkankach, poprawia elastyczność.

Placówka oferuje usługi lecznicze, hotelarskie, gastronomiczne i inne zapewniające niezbędną opiekę, a także personel. Pacjentami są klienci ubezpieczalni zdrowotnej w kategorii A - zwrot za kompleksową opiekę zdrowotną, usługi hotelarskie i gastronomiczne, w kategorii B - zwrot świadczeń zdrowotnych. Usługi dla klientów z Polski nie są finansowane przez ubezpieczalnie. Taka sama sytuacja jest $\mathrm{w}$ leczeniu pacjentów słowackich w uzdrowisku polskim.

Oczywiście dochody uzdrowiska od zakładów ubezpieczeń zdrowotnych nie obejmują wszystkich kosztów, w związku z tym firma „PIENINY Resort” oferuje produkty turystyki uzdrowiskowej na zasadach komercyjnych. $\mathrm{Na}$ przykład lecznicze zabiegi, spa wellness, wyjazdy rekreacyjne, konferencje i wydarzenia, prezentacje firm, imprezy kulturalne i sportowe, wesela, uroczystości rodzinne, święta wielkanocne są dodatkowo opłacane przez zamawiającego.. Dziś komercyjna klientela należy do ważnych gości ze względu na fakt, że przychody uzdrowiska z ubezpieczenia zdrowotnego maleją we wszystkich uzdrowiskach słowackich. Komercyjni kuracjusze z Polski stanowią znikomą grupę, dlatego większe wysiłki marketingowe mogą zmienić sytuację. 
Nowy, niedawno wybudowany dom z wyjątkiem balneoterapii oferuje hotel z 51 łóżkami i centrum kongresowym. Dziewięć apartamentów i siedem pokoi dwuosobowych z możliwością dostawki spełniają kryteria nowoczesnych usług hotelowych. Każdy pokój ma swój oryginalny układ. Sala kongresowa na 100 miejsc ze sprzętem audiowizualnym, oferuje możliwość organizowania różnego rodzaju konferencji, seminariów, warsztatów, wykładów, wystaw, prezentacji. Odnowiona wioska $\mathrm{z}$ domkami zapewnia standardowe zakwaterowanie $\mathrm{w}$ zmodernizowanych domkach $\mathrm{z}$ własnym ogrzewaniem. Każdy domek posiada dwie sypialnie, pokój dzienny oraz łazienkę. Odnowa wyciagu narciarskiego jest okazją do zdobycia potencjalnych klientów w okresie zimowym. Sporty zimowe razem z pobytem Wellness to pożądany produkt, który odpowiada tendencji rozwoju turystyki.

Usługi cateringowe są w stylowej restauracji budynku Dunajec Village, gdzie znajdują się dwie sale restauracyjne na 120 miejsc, eleganckie pomieszczenia, przeszklona oranżeria, sala z kominkiem i tarasem. W uzdrowisku jest mały pawilon pitnej wody, gdzie można uzyskać wodę Smerdžonka bezpłatnie. W parku została zainstalowana fontanna ze strefą relaksacyjną oraz kaplica. W amfiteatrze znajdują się stragany okolicznościowe. Długoterminowym celem właścicieli jest zbudowanie nowoczesnego uzdrowiska.

Ponieważ uzdrowiska w Czerwonym Klasztorze i Szczawnicy znajdują się z dala od dużego skupiska turystów, turyści odwiedzający Pieniny mają możliwość poznawania szerokiego obszaru. Z obserwacji ruchu słowackich i polskich turystów wynika, że przechodzący przez polsko-słowacką granicę polscy turyści stanowią 90\%, goście ze strony słowackiej to około 10\%. Duży natłok turystów, zwłaszcza rowerzystów, jest w szczególności wokół domku Pieniny w Leśnicy, Pienińskiej ścieżce, w muzeum byłego klasztoru kartuzów i kamedułów oraz nowowybudowana kładka przez rzekę Dunajec, która łączy wioski Czerwony Klasztor i Sromowce Niżne. Dwa miasta uzdrowiskowe nie są głównym celem turystycznym danego Euroregionu, zatem widzimy dużą rezerwę w rozwoju międzynarodowej turystyki socjalnej.

Dla realizowanego badania wybrano losowo kuracjuszy w uzdrowisku Czerwony Klasztor-Smerdžonka, pokazuje to pozytywne i negatywne uwagi w odniesieniu do ekologii. Pozytywne: spokojne miejsce, lecznicze wody, cisza, pomocny personel, piękno otaczającej natury, świeże powietrze, nowoczesne budynki, piękny projekt architektoniczny budynków, możliwość bezproblemowej wizyty w Polsce, możliwości turystyczne, spływ. Negatywne: nudne 
miejsce, słabe połączenie transportowe, brak tradycji kontynuacji uzdrowiska, nieprzygotowane i nieoznakowane szlaki turystyczne, wielu rowerzystów na ścieżce Pienińskiej, zagrożona kąpiel w rzece Dunajec (tratwy i zimna woda z powodu zapory), brak sklepów, słabo rozwinięta turystyka, brak basenu.

W przypadku tej oceny goście potwierdzili przydatność uzdrowiska Czerwony Klasztor-Smerdžonka do realizacji ekoturystyki, ale także wskazują na niewykorzystany potencjał.

W tym względzie należy zauważyć, trwającą budowę Wellness Centra koło domku Pieniny w Leśnicy. Budowa odbywa się dzięki wsparciu finansowemu $\mathrm{z}$ funduszy unijnych $\mathrm{w}$ celu wspierania euroregionów.

\section{Badanie źródeł mineralnych}

Wyjściowym punktem dla rozwoju turystyki uzdrowiskowej jest istnienie badań źródeł i wód mineralnych. Przedstawiono krótki zarys badań wody mineralnej w Smerdžonce.

Dekretem Marii Teresy z 1763 roku nakazano spisać wody mineralne w austro-węgierskiej monarchii. Wyniki tej pierwszej oficjalnej rejestracji przetworzył Johann Heinrich von Cranz w pracy Gesundbrunnen der oesterreichischen Monarchie, który został wydany w Wiedniu w 1777 r. Miejska zamagurska gwara pierwszy raz nazwała wodę "smerdzonka" i ta nazwa pojawia się w literaturze balneologii jako jasny dowód istnienia dawnych źródeł mineralnych. Johann Jacob von Engel był prawdopodobnie pierwszym analitykiem wód mineralnych. Polecał je do każdego leczenia, w którym wymagany jest siarkowodór. O Smerdžonce wspomniano w 1827 roku w pracach Die besuchtesten Badeörter, Physikalisch-medicinische Darstellung der bekannten Heilquellen der vorzüglichsten Länder Europas, które zostały wydane w 1829-1832 roku v Berlinie. W roku 1845 EJ Koch ocenił źródła zauważając, że nie są w pełni wykorzystane. Dr David Wachtel w pracy Urgans Kurorte und Mineralquellen 1859 opisuje 318446 stron i źródeł Spa, w tym Smerdžonka. Koch chwali efekt wody mineralnej i piękno okolicy Smerdžonka. Samuel Weber w swoich studiach Geschichts und Zeitbilder wydane w Levoci w 1880 r. wspomina, że Smerdžonka ma charakterystyczny intensywny i przenikliwy zapach i smak. Aurel Scherfel w 1884 r. dokonał szczegółowej analizy wody w Smerdžonce, który opublikował w pracy Analyse des Schwefelwassers z Bades Smerdžonka w 1885 roku. Z kolei Jan Buchta- 
la z Uniwersytetu Komeńskiego w Bratysławie w 1928 roku analizował źródło o nazwie Kupalny i okazało się, że Glauberowska woda zawiera 1,03925 grama minerałów na litr wody.

Po zarejestrowaniu w 1959 roku źródeł mineralnych w Czerwonym Klasztorze były trzy źródła wód mineralnych, zbudowane $\mathrm{z}$ aluwialnych warstw potoku Lipník. Woda mineralna mieszała się w niej z czystą wodą, więc jakość, zawartość siarkowodoru się zmieniała. W optymalnych warunkach, siarkowodór osiągnął wartość $5 \mathrm{mg}$ na litr wody.

Z inicjatywy Inspektoratu Uzdrowiska i Źródeł w Bratysławie, który prowadził Peter Krahulec, w roku 1973 i 1974 przeprowadzono hydrogeologiczną eksplorację źródeł mineralnych w rejonie Czerwonego Klasztoru - uzdrowisko. Głównym badaczem w zadaniu był Milan Klago. Zadaniem badania było określenie możliwości poprawy wychwytywania wody mineralnej w okolicy i na podstawie określonej pojemności zasobów zdecydować, jakie będzie ich dalsze wykorzystanie. Przed przystąpieniem do wykonywania czynności poszukiwawczych w rejonie uzdrowiska Czerwony Klasztor, istnieją trzy źródła wody mineralnej znane jako: Źródło mineralne I, Źródło mineralne II, Źródło mineralne III. Wszystkie trzy źródła mineralne są oceniane według CSN 868000 jak: naturalne, siarczan wodorowęglanu sodu, wapnia, magnezu, siarki, wody zimnej, hipotoniczna całkowita mineralizacja 1439,60 do $1604,2 \mathrm{mg} / 1$.

\section{Charakterystyka naturalnych wód leczniczych w chwili obecnej}

Źródło Smerdžonka, zarejestrowane jako odwiert CKB 2A, numer rejestracyjny (PD-140) znajduje się w oddzielnym budynku technicznym, gdzie znajduje się sprzęt obsługi, podłączenie elektryczne pompy, przepływomierz, i sprzęt monitorujący. Przestrzeń pozwala na wykonywanie pomiarów systemu i ewentualne prace manipulacyjne. Wody w budynku technicznym gromadzą się $\mathrm{w}$ dwóch zbiornikach o pojemności $10 \mathrm{~m}^{3}$. Ze zbiornika, za pomocą pompy wyciagana jest woda kierowana do wymiennika, gdzie jest ogrzewana do temperatury $14^{\circ} \mathrm{C}$, a następnie ,przekazywana” do kąpieli podwójnych. Tutaj woda ogrzewa się dalej do temperatury $35^{\circ} \mathrm{C}-40^{\circ} \mathrm{C}$, ale nie powinna przekraczać $60^{\circ} \mathrm{C}$, w przeciwnym wypadku eliminują się składniki lecznicze. Użyta woda z wanny jest ogrzewana i czysta woda odprowadzana ze studni, a następnie wpada do pobliskiego potoku Lipnik. Naturalna woda lecznicza ma kolor jasny, pod wpływem słabego ogrzewania i dotlenienia może stać się czarna. Pań- 
stwowa Komisja w swojej decyzji ustaliła maksymalną na starcie 0,33 1/s oraz maksymalną przy opuszczaniu 3,71 m/645,71 m.n.m. (npm). Woda jest średnio zmineralizowana, sulfonamidy, siarczan wodoru gazowany, sodnohorečnato wapń, sylfidická alkaliczna, słabo zimna. Całkowita mineralizacja wynosi $1172 \mathrm{mg} / \mathrm{l}$. Oprócz źródła PD-140, są tutaj trzy kolejne pasma PD-1, PD-2 i PD-3 odprowadzane na jeden wylot. Ponieważ obecnie nie są używane, spływają do rzeki.

Nazwa źródła i jego oznaczenie techniczne są umieszczone w widocznym miejscu w uzdrowisku Czerwony Klasztor-Smerdžonka. Kontrole i prawidłowe korzystanie ze źródła zapewnia techniczny pracownik uzdrowiska.

Zużycie wody mineralnej ze studni CKB 2A w okolicy Czerwonego Klasztoru jest niezbędne by chronić obszar przed niekorzystnym działaniem, który może negatywnie wpłynąć na naturalny system wody mineralnej. Granica I-szego stopnia strefy składa się z zamkniętego wieloboku wokół 2A źródła CKB (oraz niektórych innych niewykorzystanych środków). Obszar ochronny w rekreacyjnej części Dunajec, od strony północno-wschodniej tworzy strumień Lipnik, od zachodu jest granica prowadzona pod skarpy strefy buforowej, południową granicę tworzy granica katastralna między miejscowościami Czerwony Klasztor i Lechnica do skrzyżowania granicy katastralnaej z potokiem Lipnik.

W I stopniu strefy ochrony jest zabronione:

- przetwarzanie odpadów w dodatku do swojej kolekcji i usuwania,

- przeprowadzanie posypu chemicznego,

- używanie chemicznych środków ochrony roślin i łąk, w dodatku muszą być wpisane do wykazu dozwolonych środków ochrony roślin,

- palenie wszystkich rodzajów odpadów,

- transport i przechowywanie oleju, paliwa i chemikali,

- przeprowadzanie drenażu i prac irygacyjnych, melioracji, piaskowania i wykopów,

- budowanie studni i innych źródeł wody w czwartorzędowych osadach, uprawnionych do zbierania i usuwania ich z wód gruntowych bez pozytywnej oceny oddziaływania na naturalnych składnikach leczniczych przygotowanych przez osobę upoważnioną,

- przeprowadzanie wydobywania żwiru i ziemi. 


\section{Podsumowanie}

Turystyka uzdrowiskowa jest jedną z opcji rozwoju ekoturystyki na słowacko-polskiej granicy w atrakcyjnej okolicy Pienin. Analiza pokazuje, że Czerwony Klasztor-Smerdzonka w porównaniu do uzdrowiska Szczawnica w Polsce ma wadę spowodowaną przerwaniem działalności uzdrowiska. Na szczęście, nie zostało utracone źródło naturalnych wód leczniczych.

Obecnie Pieniny są postrzegane jako cel podróży turystów jednodniowych. Nawet wielu "ekspertów" twierdzi, że poza spływem po Dunajcu nie ma w Pieninach nic do zaoferowania. Odnowione uzdrowisko świadczy przeciwnie, ponieważ oferuje krótko i długoterminowe pobyty lecznice i rekreacyjne. Najwłaściwszym rozwiązaniem jest stworzenie pakietu produktów z zespołu aktywów takich jak: spływ, odkrywanie historii, realizacja turystyki, jak również leczenie i relaks w uzdrowisku. Oczekuje się lepszego zarządzania po słowackiej i polskiej stronie. Ponieważ kąpiele są przyjazne dla środowiska, są przykładem do rozwoju ekoturystyki w przyszłości.

\section{Bibliografia}

Rozporządzenie Ministra Węgierskiego Zgromadzenia Ogólnego Spiszu z dnia 21 grudnia $1887 \mathrm{r}$.

Polish-slovak borderland transport accessibility and tourism (Pogranicze polskosłowackie. Dostępność transportowa a turystyka), Wyd. IGiPZ PAN, WarszawaBratysława 2012.

Przewodnik turystyczny po Zamagurzu Spiskim, Projekt współfinansowany przez Unię Europejską z Europejskiego Funduszu Rozwoju Regionalnego oraz z budżetu państwa za pośrednictwem Euroregionu „Tatry” w ramach Programu Współpracy Transgranicznej Rzeczpospolita Polska - Republika Słowacka 2007-2013. Towarzystwo Słowaków w Polsce Zarząd Oddziału na Spiszu, Kraków 2014. 


\section{The position of the Cerveny Klastor-Smerdzonka SPA} in the Slovak-Polish border area

\section{Summary}

The tourist movement in an area is popular because of mineral water, peloids, climate, salts or sea foods. Slovakia is characterized by a plenty of thermal waters. Many of them are unused now, although in past centuries public baths were built in these places very often. The only example of existing and revitalised bath is the Cerveny Klastor-Smerdzonka, situated by the Dunajec River close to the Slovak-Polish border. The article presents the Slovak-Polish border area as a part of subsystem of the Euroregion of Tatra; historical aspects of Smerdzonka natural resources and recent trends in usage of healing resources in that area.

Translated by: Darina Eliašová 